\title{
Social Justice 101: Intro to Cancel Culture
}

\section{Steven Kessler}

The term "cancel culture" has hurtled into popular use as a way of identifying instances of social justice mobbing-essentially, the attack on a person, place, or thing that is perceived as inconsonant with "woke” ideological narratives. When a "cancel culture" event takes place the complainants demandand often get-offenders fired, shut down, silenced, or otherwise removed from the public eye.

The students at the University of Wisconsin at Madison, for example, are calling for the removal of a statue of President Lincoln for his apparent mistreatment of Native Americans. ${ }^{1}$ The San Francisco public school board is making the same accusations against Lincoln, and are attempting to expunge his name from any of their school buildings. ${ }^{2}$ A long list of examples of cancel culture on campus-the epicenter of the mobbing maelstrom-is provided in Campus Reform's “Burned: ‘cancel culture' claims multiple victims in 2020.”

So what's driving this cultural movement? Where has this new ethic and sense of morality come from? Almost all the modern iterations of leftist ideology we are dealing with in the present come from Jean-Jacques Rousseau, who once conveniently summarized the essence of his thought:

The fundamental principle of all morality, upon which I have reasoned in all my writings and which I developed with all the clarity of which I am capable is that man is a being who is naturally good, loving justice and order; that there is no original perversity in the human heart, and the first movements of nature are always good. ${ }^{3}$

1 E. Gerstmann, "Abe Lincoln is next on the cancel culture chopping block," Forbes, October 14, 2020.

2 A. Cooper, H. Brackman, "Dumping Abraham Lincoln? A word of advice to the 'cancel culture,'" The Hill, December 27, 2020.

3 J. Rousseau, "Letter to Beaumont" (1762).

Steven Kessler received his Ed.D. from the University of Rochester in Higher Education Administration. $\mathrm{He}$ is the Edmund Burke Society Fellow at the Russell Kirk Center for Cultural Renewal. Kessler's articles have appeared in numerous publications, including The Conservative, The European Conservative, and The Imaginative Conservative, 
The most important clause to this quotation is "that there is no original perversity in the human heart." The word original is an allusion to the concept of "original sin," derived from the biblical Adam and Eve, who committed the first sin by eating from the tree of the knowledge of good and evil against God's instructions, thus staining all of humanity thereafter from the moment of conception. Rousseau doesn't just invalidate original sin, he attributes natural goodness to all human beings, affirming "that man is a being who is naturally good," that human beings are born pure and are corrupted by society.

By dovetailing the invalidation of original sin with the natural goodness of man corrupted by society, Rousseau created a new ethic for interpreting right and wrong, moving responsibility for evil from the individual to society. As Irving Babbitt, a critic of Rousseau, once explained:

The old dualism put the conflict between good and evil in the breast of the individual, with evil so predominant since the Fall that it behooves man to be humble; with Rousseau, this conflict is transferred from the individual to society. ${ }^{4}$

Rousseau's transfer of the struggle for good and evil from the individual to society creates an interesting wrinkle in liberal thought: perfectibility. Man's flaws and fallen nature are removed and no longer a limitation. Arthur Melzer, a scholar of Rousseau, asserts that because evil comes from without and not from within, "then perhaps it could be overcome by reordering society. In principle, Rousseau opens up radical new hopes for politics . . that it can transform the human condition, bring secular salvation, make all men healthy and happy." ${ }^{5}$ Now that man is devoid of any evil inclination, "the appropriate manipulation of environmental factors can lead to human perfectibility," and the perfectibility of society as well. ${ }^{6}$

For Edmund Burke perfectibility was not an option: “That man thinks much too highly, and therefore he thinks weakly and delusively, of any contrivance of human wisdom, who believes that it can make any sort of perfection.”7 Burke's

4 I. Babbitt, "Democracy and leadership" (Indianapolis, IN: The Liberty Fund, orig.1924), 99.

5 A. Meltzer, The Natural Goodness of Man: On the System of Rousseau's Thought (Chicago, IL: University of Chicago Press, 1990).

6 J. Winston, From Perfectibility to Perversion: Meliorism in 18th Century France (Peter Lang, 2005$), 31$.

7 E. Burke, "A bill for shortening the duration of Parliaments" (1780). 
resolution was consistent: “There is by the essential fundamental constitution of things, a radical infirmity in human contrivance."

Rousseau negated not only the concept of original sin, but went a step further and negated the entire creation myth from the Book of Genesis. Rousseau then supplanted that creation myth for man with his own origin story, one he outlined in great detail in his essay, The Discourse on the Origin of Inequality (1755), aka, "the second discourse." According to Rousseau, the state of nature ended when someone acquired private property for himself, which did not exist otherwise.

The thrust of Rousseau's creation story in the second discourse is the contrast between the way man lived in the state of nature compared to the way we now live in civil society. This contrast between natural man in the state of nature vs. man in civil society is the birth and origin of the ideology of progressivism.

Rousseau routinely mentions "the continual progress of the human mind" in the second discourse. ${ }^{9}$ Each successive generation is superior to each previous generation. We are better than our parents; our parents are better than our grandparents; and our grandparents are infinitely better than our ancestors from antiquity. The further back in time we go after the creation, the greater the superiority of the present over the past.

This superiority of the present over the past means that the norms of the past are insufficient and cannot govern our modern and superior selves. We must destroy these old norms and standards and create new ones to better suit our new superior form. This is the rationale behind all the contemporary liberal-progressive societal tinkerings for the family unit, sexuality, and gender. The further the liberal progressivist moves from the oppressive "puritanical" norms of the old-world, the better.

The counter-argument to his belief is that human nature is not progressing, but that it is instead fixed, constant, and unchanging. Russell Kirk's commentary on this rebuttal to progressivism is illuminating: "the same vices and the same virtues are at work in every age." ${ }^{10}$ Kirk strongly advocated for the belief that, "human nature is constant. Because of that constancy, men of vision were

8 Ibid.

9 J. Rousseau, "The Discourse on the Origin of Inequality" (1755).

10 R. Kirk, Eliot and his Age: The Moral Imagination of T.S. Eliot (Willimington, DE: Intercollegiate Studies Institute, 1971), 82. 
able to describe the norms, the rules for mankind." ${ }^{11}$ Real progress therefore consists not in the creation of new norms, nor in the destruction of the old ones, but rather in adherence to the old norms. The further we move from the old norms, the closer we drift towards our own destruction.

These progressivists were originally known as "Meliorists." The Latin word meliora roughly translates to mean, “ever better.” Prominent Meliorists included William Godwin, the Marquis de Condorcet, and James Mackintosh, all of whom professed belief in the forward progress of human nature and contempt for the past. Godwin, for example, believed in "the progressive nature of man;"12 that "every generation is further removed in its physical structure from the savage;" that because of the distance from the state-of-nature to the present, "[n]othing must be sustained because it is ancient, because we have been accustomed to regard it as sacred, or because it has been unusual to bring its validity into question." ${ }^{13}$ We must be suspicious of the old by virtue of age alone. Or, to use Condorcet's phrasing, "everything that bears the imprint of time must inspire distrust more than respect." ${ }^{14}$ Condorcet shared Godwin's sentiments concerning the progressive nature of the human condition. He believed that "every prospect assures us, the human race shall not again relapse into its ancient barbarity." ${ }^{15}$ As we move further away from the state-of-nature we experience "progress in principle of conduct, and in moral conduct."16

This progressive nature of man was the impetus for Rousseau's goal: “He who dares to undertake the making of a people's institutions ought to feel himself capable... [of] changing human nature, of transforming each individual." ${ }^{17}$ That transformation of human beings has a logical concluding point for Rousseau: perfectibility, ${ }^{18}$ attainable because evil emanates not from within, but is introduced from without via society. As Jonathan Marks commented: "Perfectibility enables human beings, over time, to be altered or to alter themselves in response to circumstances.” ${ }^{19}$ Rousseau felt that perfectibility is:

11 R. Kirk, Enemies of the Permanent Things" (Peru, IL: Sherwood, Sugden, and Co., 1989), 39.

12 W. Godwin, An Inquiry Concerning Political Justice (New York, NY: Penguin Books, orig.1793), 161.

13 W. Godwin as quoted by T. Sowell in, A Conflict of Visions: Ideological Origins of Political Struggles (New York: Basic, 1987), 40.

14 J.A.N. de Condorcet, Outlines of an Historical View of the Progress of the Human Mind (London: Forgotten Books, orig. 1794).

15 Condorcet, Sketch for a Historical Picture of the Progress of the Human Mind (London: Forgotten Books, orig. 1794), 204.

16 Ibid., 211

17 J. Rousseau, "The Social Contract" (1762).

18 Melzer, The Natural Goodness of Men: On the System of Rousseau's Thought, 90; J. Marks, "Perfection and Disharmony in the Thought of Jean-Jacques Rousseau" (Cambridge: Cambridge University Press, 2005), 3.

19 J. Marks, Perfection and Disharmony in the Thought of Jean-Jacques Rousseau, 27. 
the specific gift that differentiates man from all other natural beings. ... He does not tarry in his original condition, but strives beyond it; he is not content with the range and kind of existence which are the original fights of nature nor does he stop until he has devised for himself a new form of existence that is his own. ${ }^{20}$

Rousseau's Melioristic disciples shared his optimism concerning the perfectibility of the human condition. Condorcet believed in a "[g]radual advance towards absolute perfection," ${ }^{21}$ and the "moral goodness of man susceptible to indefinite improvement." 22 Godwin interpreted Rousseau's progressivism to mean that we are, "capable of unlimited improvement." ${ }^{23}$ Godwin, like Rousseau, felt confident that the "excellencies and defects of the human character" are, "not derived from causes beyond the reach and the ingenuity to modify and correct." 24

The Meliorists of the Enlightenment and the social justice warriors of today share this sentiment. They are both confident that through their particular reconfiguration of society's norms, they can perfect the world.

This belief in perfectibility creates an environment where people are eager to find flaws in others. The moment one finds a flaw in someone or something, it is grounds for dismissal. Edmund Burke encountered this ideological position in his day with the radical Jacobins and their desire to destroy the Ancient Regime of France. Burke understood this hot-blooded desire to destroy something because it is imperfect and does not live up to a standard of perfection:

But is it in destroying and pulling down that skill is displayed? Your mob can do this as well at least as your assemblies. . . . Rage and phrenzy will pull down more in half an hour, than prudence, deliberation, and foresight can build up in an hundred years. The errors and defects of old establishments are visible and palpable. It calls for little ability to point them out. ${ }^{25}$

20 E. Cassirer, The Question of Jean-Jacques Rousseau (New Haven, CT: Yale University Press, 1989), 105.

21 Condorcet, Sketch for a Historical Picture of the Progress of the Human Mind, 31.

22 Ibid., 233.

23 W. Godwin, An Inquiry Concerning Political Justice (New York, NY: Penguin Books, origin.1793), 501.

24 Ibid, 110.

25 E. Burke, Reflections on the Revolution in France. 
If the only thing necessary to destroy an institution or an individual is finding a simple flaw, nothing is capable of standing up to scrutiny. Everything imperfect must be destroyed, and must be replaced by an idea-or more accurately, an ideal-that exemplifies the vision of the destroyers. Sir Roger Scruton shared Burke's outlook, writing that a "sentiment that all mature people can readily share: the sentiment that good things are easily destroyed, but not easily created." 26

The institutions of the past and the people who bequeathed them to us are from another era. When judging the past with the standards of the present while using a philosophical model of perfection, the past cannot stand. We must therefore destroy the past and engineer the present as we see fit.

Those who make a habit of destroying the past to build a new and better future are unfit to build the future, precisely because of their lust for destruction. As Burke said,

those who are habitually employed in finding and displaying faults, are unqualified for the work of reformation: because their minds are not only unfurnished with patterns of the fair and good, but by habit they come to take no delight in the contemplation of those things. By hating vices too much, they come to love men too little. ${ }^{27}$

The contemporary social justice warriors hate flaws more than they love strengths. This is particularly true of leftist progressives who believe in the forward march of human nature. These progressives are eager to find flaws in people, ideas, and institutions-especially from previous eras-and replace them with their own "enlightened" vision of what is good, beautiful, and true.

The social justice warriors in the present are judging the past with our contemporary standards. As Anthony Kronman wrote in The Assault on American Excellence (2019): "it is unfair to judge those who lived in an earlier age by the standards of our own.” By preserving our monuments, we are acknowledging the fact that the past is flawed, and we are able to accept that we are flawed as well. Kronman explains that “we, with our more enlightened ideals, are human

26 R. Scruton, How to be a Conservative (London: Bloomburg Publishing, 2014).

27 Burke, Reflections on the Revolution in France. 
beings, with the same imperfections as our predecessors, bedeviled by the same tendency to overestimate ourselves." 28

What Kronman is alluding to is the essence of the conservative belief that human nature is constant. We, in the present, are no different from the oldest of our ancestors. Destroying those who came before us due to their imperfections "runs the risk of encouraging the immodest belief that we not only have better values than our forebears ... but are better human beings. It makes it easier to think that we are less likely than they to be deformed." ${ }^{29}$ Monuments to flawed figures "remind us that others in the past, with human shortcomings like ours, have not always lived up to the better angels of their nature, and that we shall fail to do so as well." 30

Kronman and Burke are kindred spirits on the issue of the present inappropriately assuming superiority over the past. Burke understood history as the accumulated wisdom of our ancestors; he understood history's purpose as a guide for Mankind. He also saw the potential for Man to weaponize history and use it as an impetus for future violence:

In history a great volume is unrolled for our instruction, drawing the materials of future wisdom from the past errors and infirmities of mankind. It may, in the perversion, serve for a magazine, furnishing offensive and defensive weapons for parties in church and state, and supplying the means of keeping alive, or reviving, dissensions and animosities, and adding fuel to civil fury. ${ }^{31}$

The progressive view of continual moral improvement can lead to the inappropriate assumption of present-day superiority, and the use of history to augment that feeling. Burke understood history as the accumulated wisdom of our ancestors; he understood history's purpose as a guide for mankind. But social justice adherents weaponize and cherry-pick history to further ideological causes under different names. They use the past to penalize the present. By destroying history in this way, we destroy the reminder of all the misery we have caused each other, which then destroys a safeguard we have against causing more suffering.

28 A. Kronman, The Assault on American Excellence (New York, NY: Free Press, 2019).

29 Ibid.

30 lbid.

31 E. Burke, Reflections on the Revolution in France. 
Cancel culture is just the latest iteration of the leftist progressive agenda that seeks to destroy that which it finds imperfect. It is based on a belief in the perfectibility of man and progressivism as ideology; it is fundamentally incongruent with a realistic view of human nature, which is as sinful in the present as it was in the past.

Understanding the illogical origin of cancel culture, we can more easily accept mistakes, flaws, and errors in history, and in ourselves, as part of our fallen nature. We can more easily fight it and thus be free to preserve what is good, beautiful, and true in our legacy from the past. 